\title{
Kompleks Masjid Penampung Balita Terlantar
}

\author{
Vashti Andini dan Muhammad Faqih \\ Departemen Arsitektur, Fakultas Teknik Sipil dan Perencanaan, Institut Teknologi Sepuluh Nopember (ITS) \\ e-mail: faqih @arch.its.ac.id
}

\begin{abstract}
Abstrak-Penelantaran balita memberi dampak besar pada pertumbuhan dan perkembangan saat dewasa kelak. Diantara berbagai kabupaten/kota di Jawa Timur, Gresik memiliki jumlah kasus balita terlantar terbanyak. Hal ini diperburuk dengan area penyebaran balita terlantar yang tidak merata dan sulit terlacak. Oleh sebab itu, desain difokuskan pada area perkampungan di Gresik untuk mendekatkan solusi rancang terhadap subjek penelitian. Di sisi lain, terdapat dampak signifikan dari fasilitas umum sebagai arena pertumbuhan watak dan perilaku balita terlantar. Diantara fasilitas umum lingkungan, masjid memiliki potensi besar dalam menumbuhkan moral dan perilaku positif mereka. Dengan demikian, tujuan penulisan ini adalah memberdayakan masjid sebagai kompleks penampungan balita terlantar di area perkampungan Gresik. Teknik pengumpulan data berupa hasil observasi dan kajian literatur terkait balita terlantar dan potensi lingkungan. Data dianalisis melalui pendekatan arsitektur perilaku dengan konsep utama berupa "Lingkungan Terapi Terpadu". Metode desain yang digunakan ialah teori kontekstualime milik Kari Jormakka. Kajian lokasi didasarkan pada teori Site Analysis milik Edward T. White. Adapun hasil rancangan berupa desain pemberdayaan masjid sebagai kompleks penampungan berkonsep terapi terpadu bagi balita terlantar dalam kampung di Gresik..
\end{abstract}

Kata Kunci-Balita Terlantar, Gresik, Kampung, Masjid, Pemberdayaan, Perilaku, Terapi Terpadu.

\section{PENDAHULUAN}

$\mathrm{B}$ EBERAPA ahli berpendapat bahwa masa dini usia, yaitu masa lima tahun ke bawah, merupakan usia emas bagi perkembangan kecerdasan anak. Hanya saja tak banyak masyarakat yang memperhatikan masa keemasan pada perkembangan anak balita. Bahkan beberapa orang dewasa tega menelantarkan balitanya. Padahal fenomena penelantaran anak, khususnya pada usia dini, membawa efek samping yang buruk bagi pengembangan otak anak selanjutnya. (Gambar 1)

Di Jawa Timur sendiri, kasus penelantaran balita di tahun 2014 mencapai 18.191 jiwa. Dari banyaknya kasus balita terlentar di beberapa daerah, prosentase terbesar penelantaran berada di Kota Gresik dengan total 8.830 balita. (Tabel 1)

Besarnya jumlah penelantaran tersebut rupanya tidak seimbang dengan kemampuan penanganannya. Hal ini dapat terlihat dari sedikitnya jumlah penampungan yang khusus menangani balita terlantar. Terlebih lagi, kasus penelantaran memang sulit terlacak akibat penyebarannya yang tak merata. Oleh karena itu, dibutuhkan penanganan pada lingkup wilayah unit kota paling dasar (kampung) untuk dapat mendekatkan solusi desain pada subjek rancang. Di sisi lain, pengasuhan balita terlantar menjadi hal yang tidak mudah sebab mereka memiliki karakter dan perilaku yang berbeda dari anak pada umumnya. Tingkat kekerasan, intensitas, serta lokasi penelantaran menjadi beberapa faktor yang mempengaruhi tumbuh kembang mereka

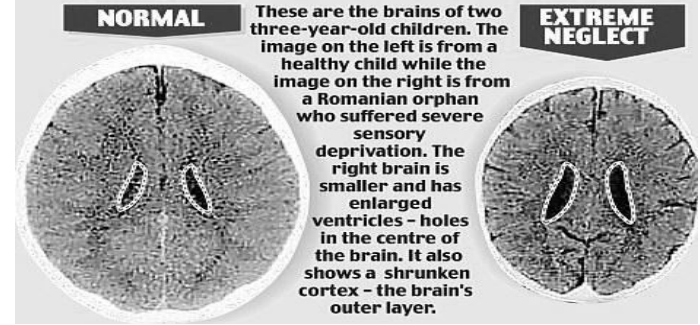

Gambar 1. Dampak jangka panjang penelantaran anak.

Sumber : http://kyyouth.org/long-term-effects-of-child-abuse-and-neglect/

Tabel 1.

Data Penyandang Masalah Kesejahteraan Sosial 2014 Sumber : Data PMKS \& PSKS Dinas Sosial Jawa Timur

\begin{tabular}{|c|c|c|c|c|}
\hline \multirow{2}{*}{ No. } & \multirow{2}{*}{ Kabupaten / Kota } & \multicolumn{3}{|c|}{ Anak Balita Terlantar } \\
\hline & & $\mathrm{L}$ & $\mathrm{p}$ & Jumlah \\
\hline 1 & Pacitan & 165 & 194 & 359 \\
\hline 2 & Ponorogo & 258 & 304 & 562 \\
\hline 3 & Trenzzalek & 120 & 91 & 211 \\
\hline 4 & Tulungagung & 49 & 48 & 97 \\
\hline 5 & Blitar & 36 & 38 & 74 \\
\hline 6 & Kediri & 134 & 117 & 251 \\
\hline 7 & Malang & 28 & 29 & 57 \\
\hline 8 & Lumajang & 987 & 791 & 1778 \\
\hline 9 & Jember & 86 & 56 & 142 \\
\hline 10 & Banyuwangi & 157 & 176 & 333 \\
\hline 11 & Bondowoso & 0 & 0 & 0 \\
\hline 12 & Situbondo & 0 & 0 & 0 \\
\hline 13 & Probolingso & 23 & 35 & 58 \\
\hline 14 & Pasuruan & 48 & 42 & 90 \\
\hline 15 & Sidoarjo & 54 & 43 & 97 \\
\hline 16 & Mojokerto & 603 & 557 & 1160 \\
\hline 17 & Jombang & 37 & 29 & 66 \\
\hline 18 & Nganjuk & 76 & 632 & 708 \\
\hline 19 & Madiun & 172 & 177 & 349 \\
\hline 20 & Magetan & 212 & 317 & 529 \\
\hline 21 & Ngawi & 71 & 81 & 152 \\
\hline 22 & Bojonegoro & 284 & 303 & 587 \\
\hline 23 & Tuban & 148 & 143 & 291 \\
\hline 24 & Lamongan & 65 & 70 & 135 \\
\hline 25 & Gresik & 4508 & 4322 & 8830 \\
\hline 26 & Bangkalan & 70 & 32 & 102 \\
\hline 27 & Sampang & 45 & 33 & 78 \\
\hline 28 & Pamekasan & 338 & 363 & 701 \\
\hline 29 & Sumenep & 31 & 22 & 53 \\
\hline 30 & Kota Kediri & 2 & 5 & 7 \\
\hline 31 & Kota Blitar & 8 & 4 & 12 \\
\hline 32 & Kota Malang & 2 & 2 & 4 \\
\hline 33 & Kota Probolingao & 59 & 51 & 110 \\
\hline 34 & Kota Pasuruan & 48 & 32 & 80 \\
\hline 35 & Kota Mojokerto & 1 & 3 & 4 \\
\hline 36 & Kota Madiun & 49 & 60 & 109 \\
\hline 37 & Kota Surabaya & 5 & 8 & 13 \\
\hline 38 & Kota Batu & 1 & 0 & 2 \\
\hline & & & & \\
\hline & Jumlah & 8980 & 9210 & 18191 \\
\hline
\end{tabular}

Dalam hal ini, kondisi lingkungan mengambil peran penting bagi kehidupan balita terlantar. Tanpa adanya arahan dari orang dewasa yang bertanggung jawab, balita yang ditelantarkan di jalanan, pasar, terminal ataupun daerah kumuh kebanyakan hidup tanpa aturan yang bersifat legalistik. Mereka cenderung tumbuh menjadi pribadi yang kasar, semaunya, apatis terhadap aturan luar yang mengekang dan egoisme yang tinggi. 


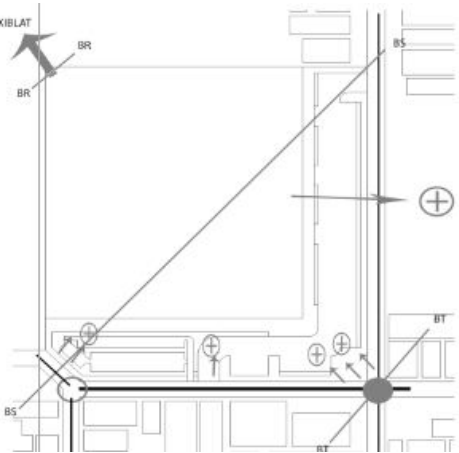

(†) VEW MENUJU ThanK

(†) ทाт кLWAR tapax

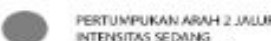

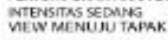
PERTUAFUKAN ARAH I IALA

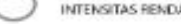

BR GISING MENDAM

as aising SKDANG

at BSING TINGGI

Gambar 2. Sumbu desain dalam tapak.

Sumber : Dokumentasi Pribadi

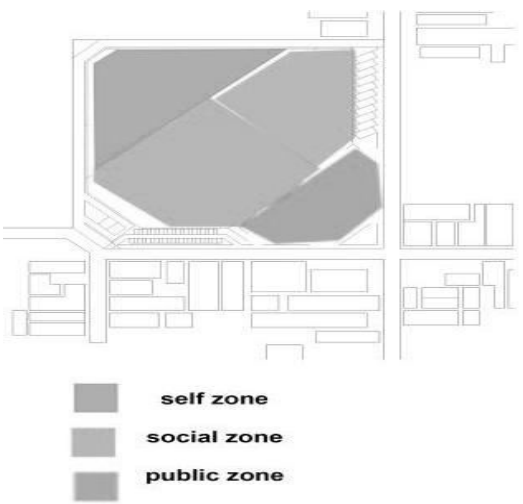

Gambar 3 .Konsep zoning.

Sumber : Dokumentasi Pribadi

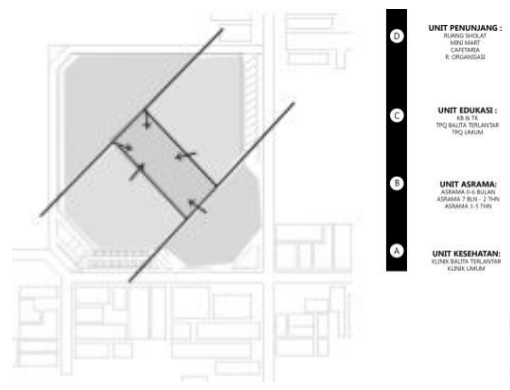

Gambar 4 . Konsep tatanan massa.

Sumber : Dokumentasi Pribadi

Berbeda halnya dengan balita terlantar yang ditemukan di rumah sakit, rumah ibadah, ataupun rumah komunitas. Mereka memiliki emosi yang lebih terkontrol sebab mendapat perlakuan yang lebih layak dari orang dewasa di sekitarnya.

Menilik besarnya pengaruh lingkungan tersebut, penulis menganalisis kapabilitas pelayanan sosial terhadap lokasi penelantaran yang ada. Dalam hal ini, masjid memiliki peluang yang cukup tinggi untuk diintegrasikan sebagai tempat pelayanan sosial balita terlantar.

Selain karena keberadaannya sebagai fasilitas kedua terbanyak yang tersebar di penjuru Indonesia, masjid memiliki komunitas religi yang dapat secara langsung diberdayakan untuk melakukan bakti sosial. Masjid juga mampu memberikan pengajaran terhadap balita terlantar sehingga tidak hanya berhenti pada pengembangan otak namun juga karakter mental yang sehat.

Namun, kebanyakan masjid hanya dipandang sebagai area ibadah formal sehingga hanya sedikit yang digunakan di luar

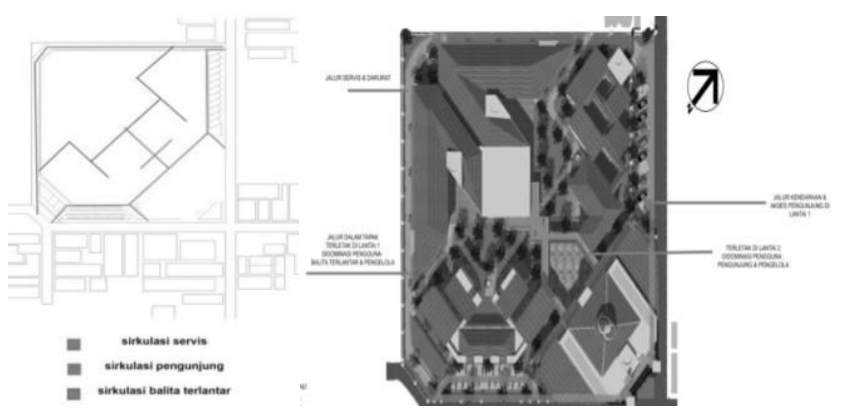

Gambar 5 .Konsep sirkulasi. Sumber : Dokumentasi Pribadi

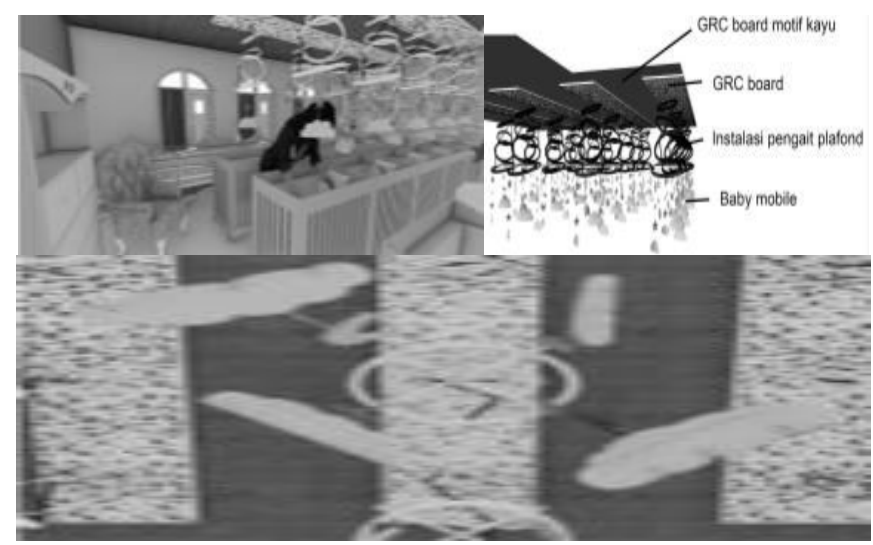

Gambar 6 . Konsep Ruangan Banota. Sumber : Dokumentasi Pribadi
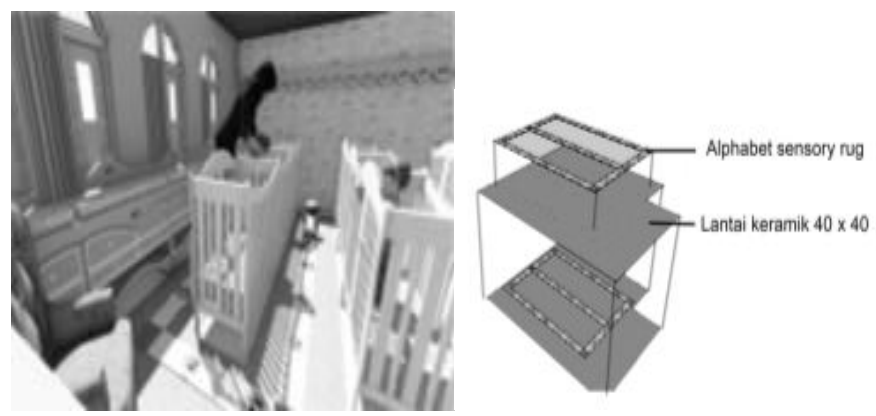

Gambar 7 . Konsep Ruangan Baduta. Sumber : Dokumentasi Pribadi

aktivitas sembahyang. Akibatnya tak banyak orang yang menaruh perhatian lebih untuk memakmurkan masjid.

Oleh sebab itu, dengan adanya desain kompleks masjid penampung balita terlantar di area perkampungan kota Gresik diharapkan mampu memberdayakan kembali fungsi masjid sebagai pusat aktivitas masyarakat dan dapat mendukung kebutuhan hidup balita terlantar yang ditampung di dalamnya.

\section{PENDEKATAN DAN METODA PERANCANGAN}

Pendekatan rancangan "Kompleks Masjid Penampung Balita Terlantar" yang digunakan untuk dapat menyesuaikan kebutuhan pengguna (balita terlantar) ialah melalui arsitektur perilaku. Pendekatan perilaku menekankan pada hubungan dialektik antara ruang dengan manusia dan masyarakat yang memanfaatkan atau menghuni ruang tersebut. 


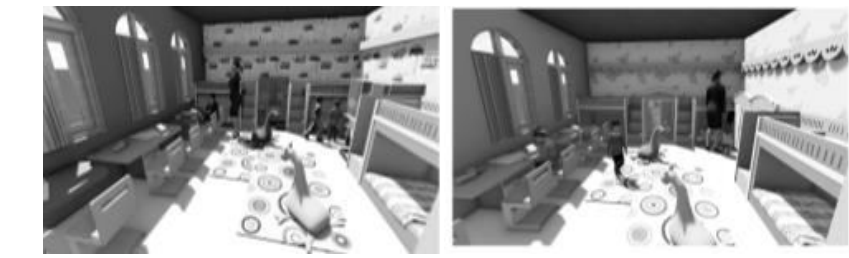

Gambar 8 .Konsep Ruangan Balita.

Sumber : Dokumentasi Pribadi

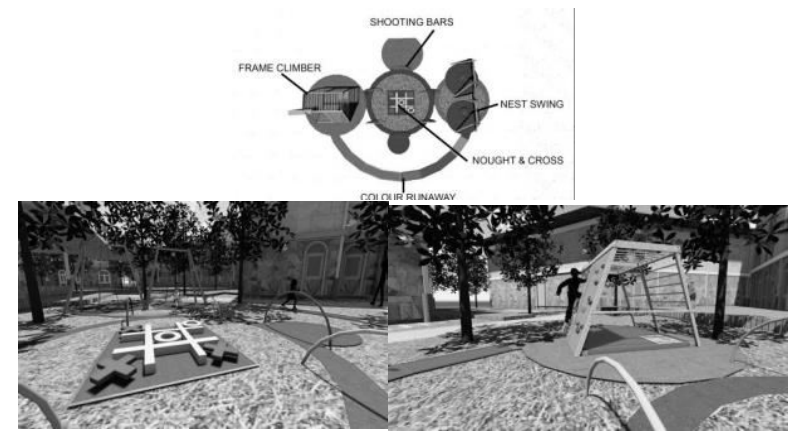

Gambar 9 .Konsep Outdoor Playground.

Sumber : Dokumentasi Pribadi

Beberapa poin utama yang perlu diperhatikan dalam proses pendekatannya yakni :

- Interaksi antara manusia dan lingkungan

- Setting perilaku

Perilaku manusia memiliki keterkaitan dengan suatu setting fisik. Variabel yang berpengaruh terhadap perilaku manusia, antara lain : ruang; ukuran dan bentuk; perabot dan penataannya; warna ; suara, temperatur dan pencahayaan.

- Perilaku spasial

Perilaku spasial merupakan pola perilaku individu atau sekelompok individu yang didasarkan pada kepemilikan ruang fisik yang terdefinisi, objek atau ide yang melibatkan pertahanan, personalisasi, dan penandaan. Faktor kunci dalam pengelompokannya adalah tingkat kebutuhan privasi, keanggotaan atau akses yang diperbolehkan.

Adapun sesuai pendekatan perilaku, penulis mengkaji beberapa perilaku khusus dari balita terlantar agar dapat menjadi pertimbangan pada objek rancang. Menurut jurnal online In Brief: The Science of Neglect, anak usia dini yang mengalami penelantaran dengan tingkat kekerasan dan durasi yang tinggi di lingkungan membuat berbagai dampak seperti :

- Kesulitan mengendalikan emosi diri

- Ketidakmampuan memahami situasi dan kondisi diri

- Memiliki kepercayaan diri yang rendah sehingga sulit mengambil keputusan

- Ketidakmampuan bersosialiasi dengan orang lain (dewasa atau sebaya)

Sedangkan metoda desain yang digunakan dalam rancangan ialah metoda kontekstualisme. Kontekstualisme dalam arsitektur memiliki arti merancang sesuai konteks. Kontekstualisme sendiri dibagi menjadi kontras dan harmoni.

Oleh karena tumbuh kembang pengguna dalam objek rancang (balita terlantar) berkaitan erat dengan lingkung bina sosial yang ada, maka peran lingkungan terbangun menjadi penting untuk dipertimbangkan dalam desain. Dengan

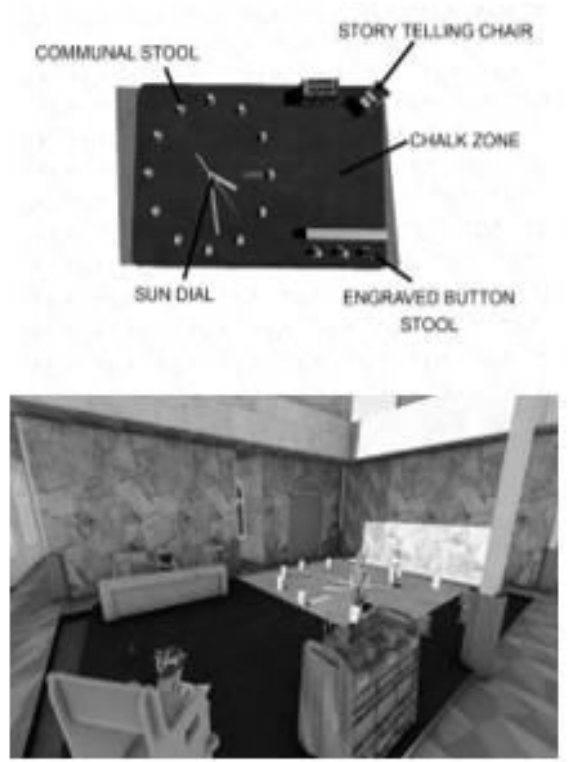

Gambar 10 . Konsep Socio Explore Area.

Sumber : Dokumentasi Pribadi

demikian, konteks yang menjadi rujukan pertimbangan desain adalah pengaruh lingkungan kampung dan perilaku khusus balita terlantar. Sehingga objek rancang nantinya dituntut untuk bisa menyelaraskan dengan lingkungan dan pengguna yang ada. (Gambar 2)

\section{HASIL DAN EKSPLORASI}

Objek rancang merupakan objek yang mengakomodasi kebutuhan masyarakat, khususnya balita terlantar sebagai sasaran rancang. Oleh sebab itu, konsep yang diambil ialah "Integrated Therapeutic Environment".

Therapeutic environment sendiri pada dasarnya merupakan upaya yang diciptakan oleh psikolog, psikiater, dan arsitek dalam memberikan pemulihan terhadap gangguan fisik \& psikis manusia. Hanya saja pada kasus ini, integrasi desain lingkungan terapi dimaksudkan untuk menciptakan pemberdayaan masjid yang lebih komprehensif (menyeluruh) dalam menangani pemulihan balita dari trauma penelantaran.

Oleh sebab itu, integrated therapeutic environment ini mencakup prinsip pemulihan baik fisik, kognitif, dan psikososial balita terlantar, seperti:

- Control (melibatkan upaya pengasuhan dan pengendalian)

- Secure (melibatkan upaya keamanan fisik dan non fisik)

- Empower (melibatkan kesempatan partisipasi aktif balita terlantar)

- Re-connect (melibatkan kesempatan sosial skala kecil hingga besar

Adapun poin poin tersebut tercermin dari konsep mikro yang dihadirkan pada objek rancang, sebagai berikut :

\section{A. Konsep zoning}

Oleh karena balita terlantar kesulitan menerima dinamisme lingkungan maka dibutuhkan upaya transisi yang baik dan nyaman. (Gambar 3)

Dalam hal ini diperlukan spasial zoning yang bertahap sesuai dengan psikospasial balita terlantar, yakni: 


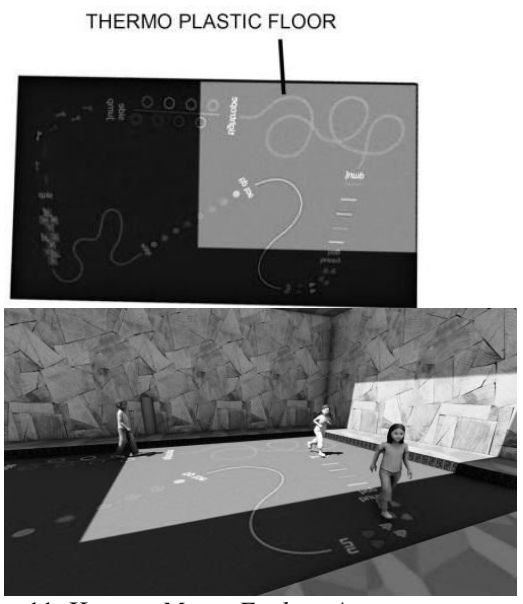

Gambar 11. Konsep Motor Explore Area.

Sumber : Dokumentasi Pribadi

- Self zone

Area ini memberi kesempatan privasi balita terlantar dalam mengenali dirinya sendiri.

- Social zone

Area dimana mulai terdapat pengaruh hubungan dari orang terdekat, seperti pengasuh dan teman sebaya. Area ini diperlukan untuk mengajarkan interaksi sosial sebelum balita terlantar memasuki skala sosial yang lebih besar

- Public zone

Area dimana balita terlantar sudah dirasa mampu melakukan interaksi dengan banyak orang di lingkungan tanpa harus menimbulkan konflik

\section{B. Konsep tatanan massa}

\section{1) Control zone}

Massa diletakkan saling berhadapan untuk membantu meningkatkan pengawasan terhadap balita terlantar. Pemantauan yang intens dibutuhkan sebab balita terlantar mayoritas kurang paham akan situasi lngkungan akibat melemahnya daya pikir mereka. Hal ini juga berguna untuk mencegah konflik sosial pada balita terlantar saat berkomunikasi dengan sesamanya. (Gambar 4)

Terdapat 4 unit massa dalam tapak yang memfasilitasi kebutuhan balita terlantar maupun masyarakat sekitar, yakni :
A. Unit Kesehatan
Terdiri atas klinik balita terlantar dan klinik umum
B. Unit Asrama
Terdiri atas asrama banota, baduta, dan balita.
C. Unit Edukasi
Terdiri atas ruang kelas balita terlantar dan TPQ
D. Unit Utama \& Penunjang

Terdiri atas ruang sholat, ruang organisasi sebagai unit utama. Perpustakaan, cafetaria, ruang serbaguna, dan minimart sebagai unit penunjang.

\section{Konsep sirkulasi \\ 1) Oriented Circulation}

Balita terlantar mudah merasa ketakutan bertemu dengan orang baru. Di sisi lain, masjid sudah seharusnya memberi kesempatan bagi semua orang berkunjung untuk beribadah (formal - non formal). Oleh sebab itu, waktu kunjungan sosialisasi dengan balita terlantar pun perlu ditentukan.
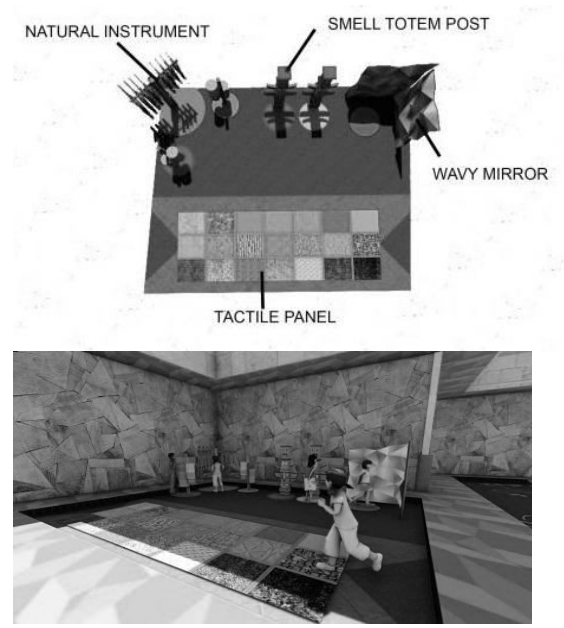

Gambar 12 . Konsep Sensory Explore

Melalui jalur utama yang terarah, akses pengunjung akan lebih terkontrol dan balita terlantar mendapat perasaan aman

2) Separate Age

Tiap jenjang usia memiliki kadar kemampuan beraktivitas. Untuk usia banota ( $0-6$ bulan) dan baduta ( 7 bulan -2 tahun) lingkup gerak hanya sebatas ruang kecil. Sedangkan usia balita (3-5 tahun) membutuhkan ruang gerakyang luas karena merupakan masaekplorasi lingkungan. Oleh sebab itu sirkulasi akan dibagi sesuai jenjang usia. (Gambar 5)

\section{Konsep ruangan}

\section{1) Unique Stimulation Room}

Pada banota (0-6 bulan) yang hanya beraktivitas tidur dan terlentang, daya visualnya berkembang cepat. Oleh sebab itu, permainan elemen plafond sangat penting untuk merangsang tumbuh kembang otaknya. (Gambar 6)

Pada baduta (7 bulan-2 tahun) sudah mulai merangkak dan memahami kata. Oleh sebab itu, permainan elemen lantai berperan penting sebagai stimulus motorik dan sensorik mereka. (Gambar 7)

Pada balita (3 - 5 tahun), tahap belajar komunikasi menjadi hal yang rumit bagi balita terlantar. Oleh sebab itu, dibutuhkan area sosialiasi dalam ruangan untuk tetap mengajarkan balita terlantar dalam mengendalikan emosi dan ego mereka. (Gambar 8)

\section{E. Konsep ruang luar}

1) Small group landscape

Oleh karena balita terlantar mudah sekali ketakutan menerima lingkungan sosial yang lebih besar. Maka ruang luar sebagai sarana interaksi sosial dibuat dalam bentuk grup grup kecil sehingga balita terlantar mudah untuk menyesuaikan.

- Outdoor Playground

Dilengkapi dengan varian permainan anak yang mampu melatih fokus, sensori \& motor balita terlantar (Gambar 9)

- Socio Exploration Area

Area ini merupakan ruang ekplorasi sosial bagi balita terlantar dalam mengembangkan kemampuan berkomunikasi \& berekspresi. Perilaku balita terlantar : tidak mudah mengendalikan emosi dan sulit mengekspresikan maksud akibat trauma yang dimiliki (Gambar 10) 
- Motor Exploration Area

Area ini merupakan ruang ekplorasi stimlasi motorik bagi balita terlantar dalam mengembangkan kemampuan fisik \& kognitif. Perilaku balita terlantar : tidak mudah memahami situasi lingkungan dan memiliki kemampuan fisik yang rendah akibat penelantaran (Gambar 11)

- Sensory Exploration Area

Area ini merupakan ruang ekplorasi stimulasi sensorik bagi balita terlantar dalam mengembangkan kemampuan indera \& kognitif. Perilaku balita terlantar : tidak mudah memahami situasi lingkungan. (Gambar 12)

\section{KESIMPULAN}

Terdapat beberapa hal penting dalam merancang fasilitas yang nyaman untuk tumbuh kembang balita terlantar, diantaranya ialah :

1. Pembentukan ruang ruang kecil sebagai sarana refleksi diri dan mengatasi kepanikan yang sering timbul akibat trauma

2. Pembentukan ruang berkelompok di beberapa titik yang berbeda untuk memicu keinginan berinteraksi sosial dan ekplorasi lingkungan lebih dalam
3. Perlunya ruang aktivitas yang memudahkan jangkauan pengawasan untuk menghindari beberapa konflik mental yang sering dialami balita terlantar sewaktu waktu

4. Perlunya permainan elemen bangunan sebagai bagian dari dukungan stimulasi yang fokus pada tiap jenjang usia balita.

\section{DAFTAR PUSTAKA}

[1] National Scientific Council on the Developing Child. (2012). The Science of Neglect : The Persistent Absence of Responsive Care Disrupts the Developing Brain. [online]. Working paper 12. Tersedia :http://developingchild.harvard.edu/wpcontent/uploads/2012/05/The-

Science-of-Neglect-The-Persistent-Absence-of-Responsive-CareDisrupts-the-Developing-Brain.pdf.

[2] Children's Bureau. (2015). "Understanding the Effects of Maltreatment on Brain Development". [online]. Tersedia : https://www.childwelfare.gov/pubPDFs/brain_development.pdf.

[3] Universitas Sumatera Utara. Pembahasan Arsitektur Perilaku. [online]. Tersedia : http://repository.usu.ac.id/bitstream/handle/123456789/50169/ Chapter\%20II.pd;jsessionid=7AD4DB42978D66720A71316E33DFF909 ?sequence $=4$.

[4] Data PMKS \& PSKS Dinas Sosial Jawa Timur 